\title{
無症候性肺塞栓症と両側上行性血栓性静脈咨を 合併した大伏在静脈瘤の一例
}

\author{
村松 賢一, 渡邊 正明
}

\begin{abstract}
○要 約：症例は 41 歳女性. 数日前から右下肢の痛みを自覚し, 腫脹拉よび発赤を認めたが改善したため 放置した．しかし，2日前から左下腿にも同様な所見を自覚したため，当院当科受診となった．血管エコーで は両側大伏在静脈に充満する血栓を認め，造影 $\mathrm{CT}$ では両肺動脈分枝部に血栓が認められた，両大腿静脈内に 及ぶ大伏在静脈内の血栓が多く認められた，手術は大伏在静脈を高位で切開し中枢の血栓を除去した後に高 位結皆を行った，術後経過良好である，本症例のように血栓が伏在静脈本管に発生し中枢へ進展していくも のは上行性血栓性静脈炎と称され深部静脈血栓症や肺塞栓症の原因となり, 時に致命的となり注意が必要で ある。
\end{abstract}

索引用語 : 上行性血栓性静脈炎, 深部静脈血栓症, 肺塞栓症

静脈学 2018; 29(3): 345-348

はじめに

表在性血栓性静脈炎は予後もよく, ありふれた疾患で あるが，血栓性静脈炎が深部静脈まで進展していく場合 があり，上行性血栓性静脈炎と称され深部静脈血栓症 （DVT）や肺塞栓症（PE）の原因となりうるため注意が 必要である，今回われわれは無症候性肺塞栓症と両側上 行性血栓性静脈炎を合併した大伏在静脈瘤の一例を経験 したので報告する。

\section{症例}

患 者: 41 歳, 女性

主 訴: 大腿部の発赤, 腫脹

家族歴：特記事項なし

既往歴：特記事項なし

現病歴：以前より両側静脈瘤は自覚されていた。数 日前から右下肢の痛みを自覚し, 腫脹および発赤を認め

会津中央病院心臟血管外科

受付：2018年5月 16日受理：2018年6月6日

doi: 10.7134/phlebol.18-09

\section{(c) BY-NC-ND}

たが改善したため放置した。しかし，2日前から左下腿 にも同様な所見を自覚したため, 当院当科受診となっ た。

入院 時現症: 身長 $164 \mathrm{~cm}$, 体重 $72 \mathrm{~kg}$, 血圧 $120 / 50 \mathrm{mmHg}$

入院時血液検査所見 : WBC6330 $/ \mu \mathrm{L}, \mathrm{Hb} 8.7 \mathrm{~g} / \mathrm{dL}, \mathrm{Hct}$ $28.4 \%$, Plt $31.1 \times 10^{4}$, (凝固) PT-INR 1.12, APTT 32.0, d-dimer 8.6 MCG/ML, (生化) CRP $18.4 \mathrm{mg} / \mathrm{dL}, \mathrm{BUN}$ $12.5 \mathrm{mg} / \mathrm{dL}$, Cr $0.49 \mathrm{mg} / \mathrm{dL}$, AST $57 \mathrm{IU} / \mathrm{L}$, ALT $60 \mathrm{IU} / \mathrm{L}$, LDH 299 U/L，プロテインC抗原量 $85 \%$ ，プロテイン C 活性 101\%, プロテイン S 抗原量 $98 \%$, プロテイン S (遊 離型抗原量) 101\%, ループスアンチコアグラント 1.1 .

心電図：洞調律, 整, 76回/分

胸部レントゲン写真 : 心胸郭比 $48 \%$

下肢血管エコー所見：大伏在静脈内に血栓を認めた

(Fig. 1).

造影 CT : 肺下葉に向かう両肺動脈分枝部に血栓が認 められた，両大腿静脈内に及ぶ大伏在静脈内の血栓が多 く認められた（Fig.2).

手術所見: 全身麻酔下に両側鼠径部を横切開し, 大 腿静脈掞よび大伏在静脈を露出した。周囲は炎症の影響 で非常に癒着していた（Fig. 3)。ヘパリン化した後に大 


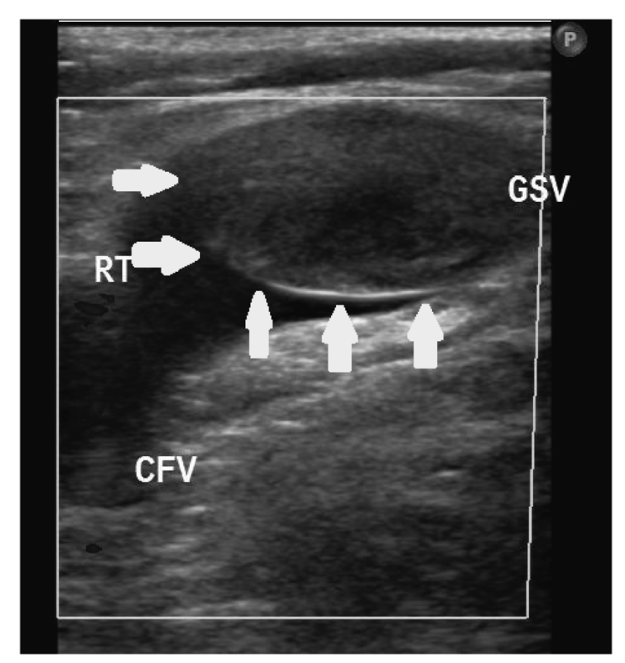

Fig. 1 Ultrasonography shows the thrombus filled in the great saphenous vein.

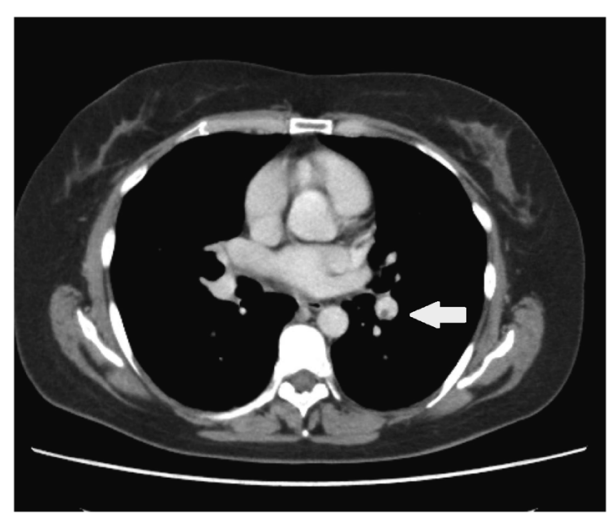

a

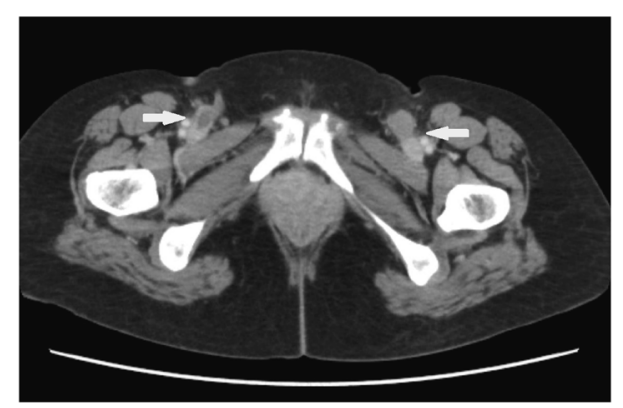

b

Fig. 2 Enhanced CT. a: A thrombus (arrow) was in the pulmonary artery, b: A thrombus (arrow) protruded in to femoral vein.

腿静脈を遮断し，大伏在静脈を切離し，内部の血栓を可 及的に除去し。高位結禁術を施行した。手術時間 1 時間 27 分.

術後経過：術直後から歩行し, 術後7日目に造影CT で術後評価を行い, 第9病日に独歩退院した。

\section{考察}

表在性血栓性静脈炎はありふれた疾患であり, 報告 に差はあるが下肢静脈瘤の $4 \sim 59 \%$ にさまざまな程度の

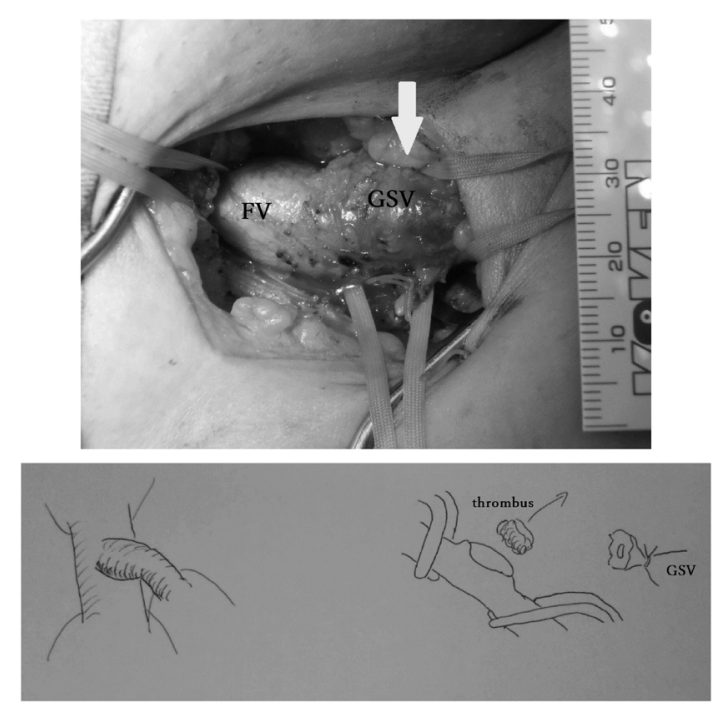

Fig. 3 The great saphenous vein on the left side was filled with thrombus (arrow). Operation was performed by incising the large saphenous vein at a high level and removing the thrombus, followed by high ligation.

血栓性静脈炎を合併するとされており，予後は良好と考 えられており，日常診療において保存的に対処されるこ とが多い ${ }^{1)}$ 。治療は弾性包帯, 非ステロイド系鎮痛剤, ヘパリン様クリームで対応する。今回の症例のように伏 在静脈本幹に発生し中枢へ進展していくものは上行性血 栓性静脈炎と称されDVTやPEの原因となり，時に致命 的となり注意が必要である2).

上行性血栓性静脈炎の6〜53\%にDVTを，0～33\%に PEを合併するが, 凝固能立進, 悪性腫瘍, 男性, DVT の既往, 高度の慢性静脈不全の既往, 静脈炎の発症から 間もないことなどが上行性血栓性静脈炎にDVTを合併 するリスクであるといわれている2,3)，本症例では慢性 静脈不全の既往と, 静脈炎が発症リスクとなっていた。

診断は，視触診および超音波検査（duplex scan）, CT, MRI，静脈造影などの画像検査がある。その中でも超音 波検査（duplex scan）が診断および血栓中枢側の評価に 有用で，簡便，安価，であることについてはコンセンサ スが得られている. CT, MRIは形態評価および肺塞栓症 の有無について可能であるが血流の方向同定は不可能で ある. 静脈造影は診断が難しく静脈炎などの合併症を起 こすこともあるため不要であることが多い，また血液凝 固異常や悪性腫瘍など血栓形成を促す全身疾患を評価す る必要がある ${ }^{2,4-6)}$.

治療方針については定まったものはなく，外科的手 術が第一選択という報告があり，ヘパリン，ワーファリ ンを使用した抗凝固療法でも合併症なく治療効果が高い とする報告もある．抗凝固療法を行い血栓の退縮や安定 を待ってから手術が選択される場合もあるが, 現時点で 
は状況に応じて治療法を選択せざるを得ない, 2)，抗凝 固療法が継続して可能であれば，保存療法で経過を見る のも可能であるが, 何らかの原因で抗凝固療法が継続不 可能であれば，外科的手術の適応となると考えられる。 本症例は生理の際の出血が多く, 貧血が強いため長期の 抗凝固療法を希望されなかったため, 周術期にへパリン 化したまま，早期に高位結紮術を施行した。また，ス卜 リッピングを追加するかどうかの結論は出ていないが, ヘパリン化したままであったため, 術後の創部からの出 血を考え施行しなかった。

下大静脈フィルターの適応は一般的には下大静脈や 腸骨静脈内のフローティングのある血栓を認める場合, 抗凝固療法無効の再発肺塞栓, 抗凝固療法禁忌例などが あげられるが，上行性血栓性静脈炎を伴う静脈瘤の手術 にもフィルターが肺塞栓の予防に有効であったとの報告 もあるが，はっきりしたエビデンスがそしい。むしろ周 術期に抗凝固療法が十分行われなかったためにさまざま な合併症が起こっている報告もあるため ${ }^{2)}$, 本症例では 下大静脈フィルターを挿入せず，周術期にヘパリンを切 らずに術式を高位結紮のみにとどめ, 出血のリスクを最 小限にし，良好な結果が得られた。

\section{結 語}

上行性血栓性静脈炎は深部静脈血栓症や肺塞栓症の
原因となりうるため，早期の治療開始と肺塞栓症の予防 が重要である。

\section{利益相反}

なし.

\author{
付 記
}

学会発表：日本血管外科学会（2017年, 広島国際会 議場）

\section{文献}

1) 斎藤 聰, 原田剛佑, 神保充孝: 無症候性肺塞栓と上行性血栓 性静脈炎を合併した大伏在静脈瘤の 1例。Jpn J Phlebol 2010; 21： 269-275

2) 新名克彦, 中村都英, 中村栄作 : 上行性血栓性静脈炎3例の経 験. J Jpn Coll Angiol 2014; 54: 31-34

3) Leon L, Giannoukas AD, Dodd D, et al: Clinical significance of superficial vein thrombosis. Eur J Vasc Endovasc Surg 2005; 29: 10-17

4) 吉田凱亮, 榎木千春, 堀口速史, 他 : 瘤内血栓による肺塞栓症を 合併した下肢静脈㽣の経験. 外科 1999; 61: 1717-1721

5) Quenet S, Laporte S, Décousus H, et al: Factors reddictive of venous thrombotic complications in patients with isolated superficial vein thrombotic complications in patients with isolated superficial vein thrombosis. J Vasc Surg 2003; 38: 944-949

6) Verlato F, Zucchetta P, Prandoni P, et al: An unexpectedly high rate pf pulmonary embolism in patients with superficial thrombophlebitis of the thigh. J Vasc Surg 1999; 30: 1113-1115 


\title{
Abstract \\ A Case of a Large Saphenous Varicose Vein with Asymptomatic Pulmonary Embolism and Bilateral Ascending Thrombophlebitis
}

\author{
Kenichi Muramatsu and Masaaki Watanabe
}

Department of Cardiovascular Surgery, Aizu Central Hospital

Key words: ascending thrombophlebitis, deep vein thrombosis, pulmonary embolism

This case involved a 41-year-old female who experienced pain in the right lower leg for a few days, Although swelling and reddening were observed, no treatment was sought because her condition improved. However, she visited our hospital after becoming aware of similar symptoms in the left lower limb two days ago. Vascular echocardiography revealed thrombus filling the bilateral great saphenous veins, and thrombus was found in the branches of both pulmonary arteries on contrast CT. A lot of thrombus was observed in the saphenous vein extending into both femoral veins. Surgery was performed by incising the large saphenous vein at a high level and removing the thrombus, followed by high ligation. The operative course was good. In this case, the thrombus arising in the main great saphenous vein and progressing to the femoral vein was diagnosed as ascending thrombophlebitis, which can cause deep vein thrombosis and pulmonary embolism, As this condition is sometimes fatal, caution is necessary.

Jpn J Phlebol 2018; 29(3): 345-348 